\title{
Sediment Management in Hydropower Dam (Case Study - Dez Dam Project)
}

\author{
H. Samadi Boroujeni \\ Shahrekord University, \\ Iran
}

\section{Introduction}

Hydropower reservoirs are loosing their capacity due to sedimentation processes, and are therefore seriously threatened in their performance. Without any mitigating measures the viability of many reservoirs in the worldwide is questionable, as the impacts and losses are not balanced by the profits. It is apparent that for mastering the reservoir sedimentation issues the use of strategies for controlling reservoir sedimentation becomes increasingly important because of sustainable development issues. Basic principles in sustainable development and use of reservoirs are:

- Human beings are at the center of concerns for sustainable development and use.

- Humans are entitled to a healthy and productive life in harmony with nature.

- Along with the right to develop and use reservoirs comes the responsibility to meet the needs of present and future generations.

To achieve sustainable development and use of reservoirs and a higher quality of life for all people, we should gradually reduce and eliminate unsustainable patterns of development and use subject to social, environmental, and economic considerations. Reservoir sedimentation shortens the useful life of reservoirs. Systematic and thorough consideration of technical, social, environmental, and economic factors should be made to prolong the useful life of reservoirs.

Approximately $1 \%$ of the storage volume of the world's reservoir is lost annually due to sediment deposition [Morris and Fan, 1998]. In some developing countries, where watershed management measures are not carried out effectively, reservoir storage is being lost at much larger rates. Although the reduction of sediment yield via a watershed management program is the best option for reducing the rate of reservoir sedimentation, flushing may be one of the most economic methods which offer recovering of lost storage without incurring the expenditure of dredging or other mechanical means of removing sediment. Flushing is the scouring out of deposited sediments from reservoirs through the use of low level outlets in a dam by lowering water levels, and thus increasing the flow velocities in the reservoir. The technique is not widely practiced because of the damages caused by the injection of high sediment concentrations to the downstream river system; involving large volumes of water being passed through the dam; being usually only effective in narrow reservoirs and requiring the reservoir to be emptied. 
Mangahao reservoir in New Zealand 59\% of the original operating storage had been lost by 1958, 34 years after the reservoir was first impounded. The reservoir was flushed in 1969, when $75 \%$ of the accumulated sediment was removed in a month [Jowett, 1984]. Another examples of reservoirs that have been successfully flushed are Baira (in India), Gebidem (in Switzerland), Gmund (in Austria), Irengshan, Honglingyin and Naodehai (in China)[Atkinson, 1996]. Another technique for decreasing Reservoir sedimentation is the passing of turbidity currents through the reservoir and low-level sluices in the dam. Turbidity currents occur when sediment-laden water enters an impoundment, plunges beneath the clear water, and travels downstream along the submerged thalweg. As the current travels downstream, it will generally deposit the coarser part of its sediment load along the bottom, and if the current reaches the dam, it can be vented through low-level outlets. For example, the records of turbidity current releases from a reservoir were made in July 1919 at Elephant Butte reservoir in the United States, where the inflow suspended sediment concentration was $72 \mathrm{~g} / 1$ and discharge from the low-level outlet at the dam was $41 \mathrm{~g} / 1$ [Lane, 1954]. Also in this subject a literature survey on different methods and their geomorphologic and sediment transport effects has been carried out by Brandt [Brandt, 2000].

It is well accepted that reservoir sedimentation poses a serious threat to available storage. The annual loss of storage in reservoirs is roughly $1 \%$ corresponding to a about $50 \mathrm{~km}$ worldwide (Mahmood, 1987). Some reservoirs have a much higher storage loss, e.g., the Sanmenxia Reservoir in China looses about $1.7 \%$ yearly. In the meantime significant transformations can occur in the stream basin due to the redistribution of sediments and discharges. Sloff (1991) reviewed these phenomena by means of a survey of the scattered literature in order to find the remaining gaps in the applied theory. Theoretical approaches are here desired to estimate the sedimentation threat and even to reconsider the design. In the past highly empirical models were used for this purpose, but often resulted in an underestimation of the actual sedimentation rate. This can be ascribed to failing theory as well as to a lack of data. For instance sedimentation rates of the Sefid-Rud reservoir in northwest Iran can be estimated with a 60 years old highly empirical approach to be about 35 million $\mathrm{m}^{3} / \mathrm{yr}$ (Tolouie et al., 1993). However, after construction (in 1962) the measured rate was about 45 million $\mathrm{m}^{3} / \mathrm{yr}$ causing a storage loss of over $30 \%$ in 1980 . The original predicted useful reservoir life of one century based on old data was found to be actually about 30 years (Pazwash, 1982). Not until 1980 flushing operations were started which were able to regain about 7\% of the lost capacity. In Dez Dam reservoir after 40 years from starting operation of the dam, the height of sediment surface behind face of the dam was reached near power intake level.

When dealing with reservoir-sedimentation problems engineers are challenged by the difficult questions emerging. How to incorporate reservoir problems in feasibility studies (cost-benefit analyses) including environmental and technical effects, limitations on benefit and possible measures? Or what is the impact of sedimentation on the reservoir performance such as power generation and water supply, and what is the impact of the reservoir on the river-system morphology? Obviously a good prediction of the processes and trying to better understanding of the reservoir behavior is essential to master the reservoir-sedimentation issues. 


\section{Reservoir sedimentation problems}

During the 1997 19th Congress of the International Commission on Large Dams (ICOLD), the Sedimentation Committee (Basson, 2002) passed a resolution encouraging all member countries to the following measures:

1. Develop methods for the prediction of the surface erosion rate based on rainfall and soil properties.

2. Develop computer models for the simulation and prediction of reservoir sedimentation processes

Extensive literature exists on the subject of reservoir sedimentation. The book by Morris and Fan (1997), entitled Reservoir Sedimentation Handbook is an excellent reference and provides an extensive list of references.

At the first time we introduce the principle processes involved with sedimentation in a storage reservoir in Fig. 1, as treated in Sloff (1991 and 1997).

The most important distribution principles of these sediments in the reservoir can be subdivided into the following groups: be subdivided into the following groups:

- Coarse sediment deltaic deposits: mainly the coarse sediment fractions are deposited in the head of the reservoir by backwater effects during high discharges, forming a delta. The delta proceeds into the reservoir while the foreset slope can be considered as an area of instability and slumping.

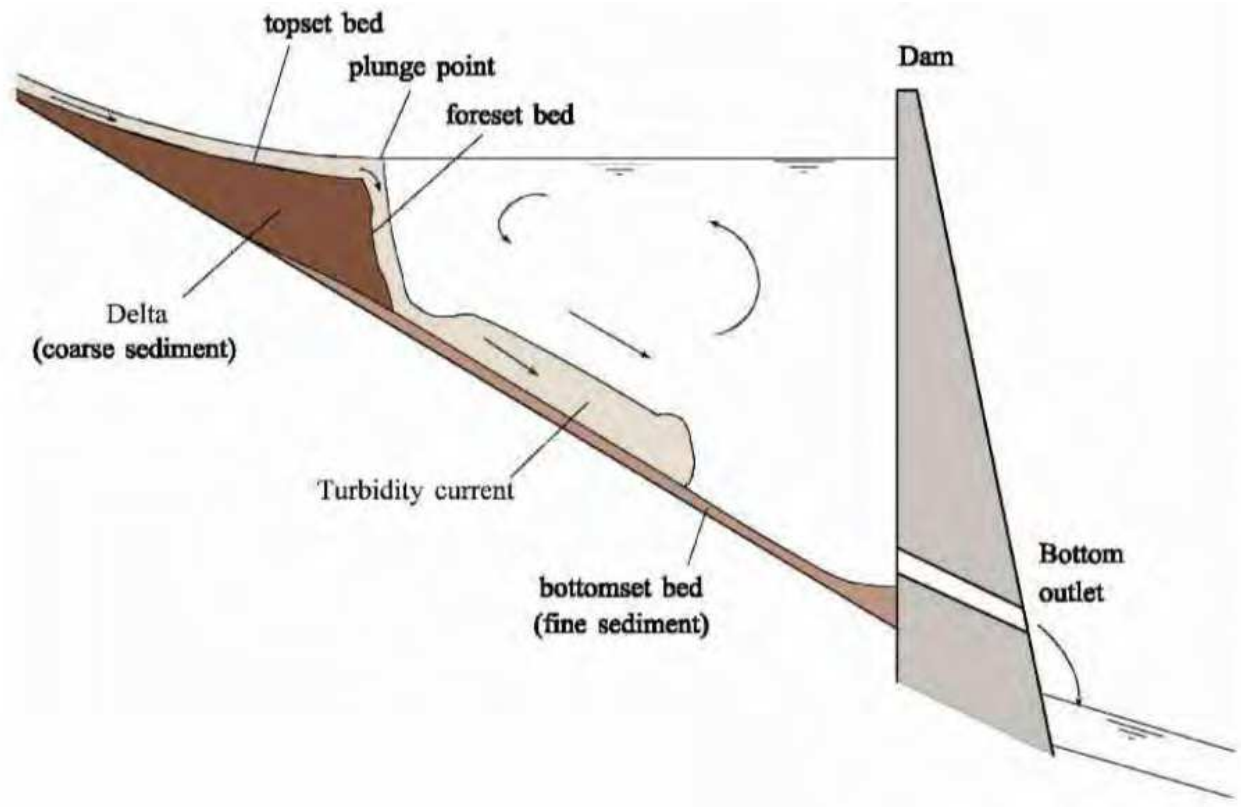

Fig. 1. Schematic presentation of principle sedimentation processes in river-fed storage reservoirs (Sloff, 1997). 
- $\quad$ Fine sediments in homogeneous flow: A large part of the fine sediments transported in suspension or as wash load are transported beyond the delta after which they settle out to form the bottom set bed. They are more evenly spread than coarse sediment, but there distribution is highly dependent on reservoir circulation and stratification, for instance generated by river inflow and wind shear, or precluded by an ice cover. Also for this type of deposition the quantification methods still yield rough predictions.

- Turbidity currents: another important transport mode for fine sediments, i.e., silt and clay, is the turbidity current. It is formed when the turbid river inflow plunges below the clear reservoir water and continues as a density underflow. Also other processes can generate them, such as underwater slides (slumping of delta front) or coastal erosion. Turbidity currents are driven by an excess gravity force (negative buoyancy) due to the presence of sediment-laden water in a clear ambient fluid.

\section{Sediment problems in hydropower plant}

The sediment management is challenging discipline in civil engineering especially in the many regions. The storage capacity of reservoirs decreases due to accumulation of sediment. Dealing with reservoir-sedimentation problems, engineers are challenged by the difficult questions emerging. How to incorporate reservoir problems in feasibility studies (costbenefit analyses) including environmental and technical effects, limitations on benefit and possible measures? Or what is the impact of silting and desilting of the reservoir?

By focusing on sediment impacts in hydropower plant the following impacts may be notified:

1. The effect of reservoir sedimentation on regulating water resources and its impact on power generation

2. The effect of sediment inflow to power intakes and its impacts on turbine system and other components of the hydropower plant.

The erosion of turbine component depend on: (i) eroding particles - size, shape, hardness, (ii) substrates-chemistry, elastic properties, surface hardness, surface morphology, and (iii) operating conditions - velocity, impingement angle, and concentration and like that. Depending on the gradient of the river and distance traversed by the sand particles, the shape and size of sediment particles vary at different locations of the same river system, whereas mineral content is dependent on the geological formation of the river course and its catchments area.

Run-of-river projects are constructed to utilize the available water throughout the year without having any storage. These projects usually consist of a small diversion weir or dam across a river to diver the river flow into the water conveyance system for power production. Therefore, these projects do not have room to store sediments but should be able to bypass the incoming bed loads to the river downstream. The suspended sediments will follow the diverted water to the conveyance system. Settling basins are constructed close to the intake to trap certain fractions of the suspended sediment (Thapa and Dahlhaug, 2003).

\section{Sediment management measures for reservoirs}

Sediment management practices for reservoirs are often as different as their physical and technical conditions and social-economic and environmental aspects. Based on literatures and existence experiences, a tentative long-list of alternatives for sediment control of dam reservoirs can be found. The list is sub-divided into four general categories as follows: 
i. $\quad$ watershed rehabilitation (Structural and non- Structural Measures)

ii. sediment flushing

iii. sediment routing

iv. sediment removal and disposal

Based on the above general categories some of the measures commonly used to reduce reservoir sedimentation are summarized in the following sections.

\subsection{Soil conservation}

This strategy focuses on reducing sediment inflow to dam reservoir. In the upstream watershed of a reservoir, three basic patterns of soil conservation measures are commonly taken to reduce sediment load entering the reservoir: structural measures, vegetative measures, and tillage practice. Structural measures include terraced farmlands, flood interception and diversion works, gully head protection works, bank protection works, check dams, and silt trapping dams. Vegetative measures include growing soil and water conservation forests, closing off hillsides, and reforestation. Tillage practice includes contour farming, ridge and furrow farming, pit planting, rotation cropping of grain and grass, deep ploughing, intercropping and interplanting, and no-tillage farming. For a large watershed with poor natural conditions, soil conservation can hardly be effective in the short term.

\subsection{Bypass of incoming sediment}

Rivers carry most of the annual sediment load during the flood season. Bypassing heavily sediment-laden flows through a channel or tunnel may avoid serious reservoir sedimentation. The bypassed flows may be used for warping, where possible. Such a combination may bring about high efficiency in sediment management. When heavily sediment-laden flows are bypassed through a tunnel or channel, reservoir sedimentation may be alleviated to some extent. In this method, however, the construction cost of such a facility may be high.

\subsection{Sediment diverting}

Sediment diverting (Warping) has been used around the world. It has a history of more than 1,000 years in China as a means of filling low land and improving the quality of salinized land. Now, this practice may have a dual role, not only improving the land but also reducing sediment load entering reservoirs. Warping is commonly carried out in flood seasons, when the sediment load is mainly concentrated, especially in sediment-laden rivers. Warping can also be used downstream from dams when hyperconcentrated flow is flushed out of reservoirs.

\subsection{Joint operation of reservoirs}

Joint operation of reservoirs is a rational scheme to fully use the water resources of a river with cascade development. For sedimentation management of reservoirs built on sedimentladen rivers, such an operation may also be beneficial to mitigate reservoir sedimentation and to fully use the water and sediment resources, provided a reasonable sequence of cascade development is made. There are various patterns of joint operation of reservoirs built in semi-arid and arid areas. The idea is to use the upper reservoir to impound floods and trap sediment and to use the lower reservoir to impound clear water for water supply. 
Another idea is to use the upper reservoir for flood detention and the lower reservoir for flood impoundment. Irrigation water in the lower reservoir is used first; when it is exhausted, the water in the upper reservoir is used. The released water from the upper reservoir may not only erode the deposits in the lower reservoir, but also cause warping by the sediment-saturated water

\subsection{Drawdown flushing}

Drawdown flushing is a commonly used method of recovering lost storage of reservoirs. It may be adopted in both large and small reservoirs. The efficiency of drawdown flushing depends on the configuration of the reservoir, the characteristics of the outlet, the incoming and outgoing discharges, sediment concentrations, and other factors. Sometimes reservoir emptying operations may be used for increasing efficiency of the flushing. In the process of reservoir emptying, three types of sediment flushing occur: retrogressive erosion and longitudinal erosion, sediment flushing during detention by the base flow, and density current venting. Environmental impacts are the most constraints for drawdown flushing.

\subsection{Venting density current}

Density currents have been observed in many reservoirs around the world. A density current may carry a large amount of sediment and pass a long distance along a reservoir bed without mixing with surrounding clear water. The conditions necessary to form a density current, and allow it to reach the dam and be vented out if the outlet is opened in time, have been studied extensively, both from the data of field measurements and laboratory tests. Venting of density currents is one of the key measures for discharging sediment from several reservoirs in the world wide. Density current venting may be carried out under the condition of impoundment, thus maintaining the high benefit of the reservoirs.

\subsection{Lateral erosion}

The technique of lateral erosion is to break the flood plain deposits and flush them out by the combined actions of scouring and gravitational erosion caused by the great transverse gradient of the flood plains. In so doing, it is necessary to build a low dam at the upstream end of a reservoir to divert water into diversion canals along the perimeter of the reservoir. The flow is collected in trenches on the flood plains. During lateral erosion, because the surface slope of the flood plain is steep and the flow has a high undercutting capability, intensive caving-in occurs at both sides of the collecting trench. The sediment concentration of the flow may be as high as $250 \mathrm{~kg} / \mathrm{m} 3$. This technique has the advantage of high efficiency and low cost, and no power or machines are required.

\subsection{Siphoning dredging}

Siphoning dredging makes use of the head difference between the upstream and downstream levels of the dam as the source of power for the suction of deposits from the reservoir to the downstream side of the dam. Siphoning dredging has a wide range of applications in small and medium-size reservoirs. Such an application is valuable to solve reservoir sedimentation 
and to fulfill the demand of irrigation if the head difference is adequate and the distance between upstream and downstream ends of the siphon is not too great.

\subsection{Dredging by dredgers}

Dredging is used to remove reservoir deposits when other measures are not suitable for various reasons. In general, dredging is an expensive measure. However, when the dredged material may be used as construction material, it may be cost effective.

\section{Overview of hydropower potential in Iran}

Iran is a vast country with an area exceeding $106 \mathrm{MKm}^{2}$ with two major Zagross and Alborz mountain ranges. Based on the mean annual precipitation of the country about $250 \mathrm{~mm}$ and its processes of transformations into water resources, the annual average precipitation is 417 Billion Cubic Meters (BCM), average annual evaporation is 299 BCM, surface water is 92 $\mathrm{BCM}$ and seepage to alluvial aquifers is $26 \mathrm{BCM}$. Further about 72 percent of precipitation is not accessible due to evaporation and transpiration and about 22 percent of precipitation flows on surface water resources and nearly 6 percent of precipitation that falls within the limits of the country in used for direct recharge of alluvial aquifers. Accounting the $13 \mathrm{BCM}$ surface flows enter into the country from across its borders, the total water resources potential is $130 \mathrm{BCM}$ of water that available for various usage and also developing hydropower plants. In Iran 310 large dams (42 concrete dams and 268 embankment dams) were constructed and 81 dams at least $60 \mathrm{~m}$ in height are under constructing and 172 dams are under study (Molanezhad, 2008).

The comparative study of dam built in Iran in last one decade to earlier three past decade indicated of increasing (56.6\%) of developing new water structure activities and increasing of $(73.6 \%)$ of completed new dams through today.

While the capacity of hydroelectric power in the National Power Industry in Iran is about $15 \%$ of the total installed power capacity, they have an important role to peak electricity production and they play a key role in stability of the National Power network. despite the potential capacity of hydropower development in Iran may be reach up to 20,000 MW, nowadays total installed hydropower capacity in Iran is about $8500 \mathrm{MW}$. So the hydropower can be a key energy sector in the National Power Industry.

\section{Case study: dez hydropower dam}

\subsection{Dez dam project background}

The Dez Reservoir is located in the Zagros Mountains in the Southwest Iran and was created by the construction in 1963 of the 203m high Dez Dam. An underground powerhouse contains eight $65 \mathrm{MW}$ units for a total installed capacity of $520 \mathrm{MW}$ which has generated an average of $2400 \mathrm{GWh} /$ year energy production over an operating period of 45 years. The minimum and maximum water level of the reservoir operation is $300 \mathrm{~m}$ and $352 \mathrm{~m}$ from sea level respectively. Flow releases are through the spillway, power tunnels and three lowlevel irrigation outlets. The original reservoir volume was 3315 million m3 and over an operating period of 40 years the storage volume was reduced to 2600 million $\mathrm{m} 3$ by sedimentation. Fig.2. shows a photo of Dez Dam Project and a plan view of Dez reservoir. 
a.

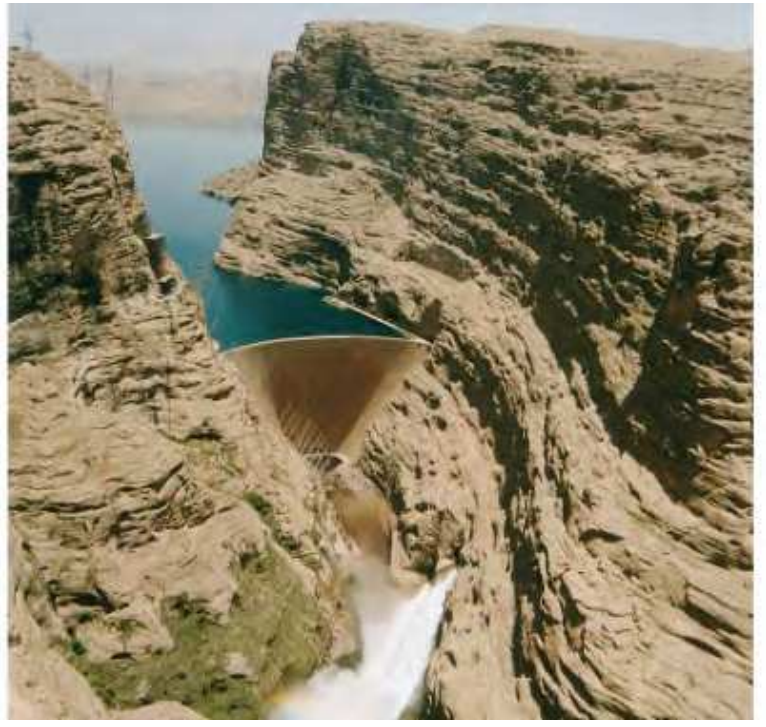

b.

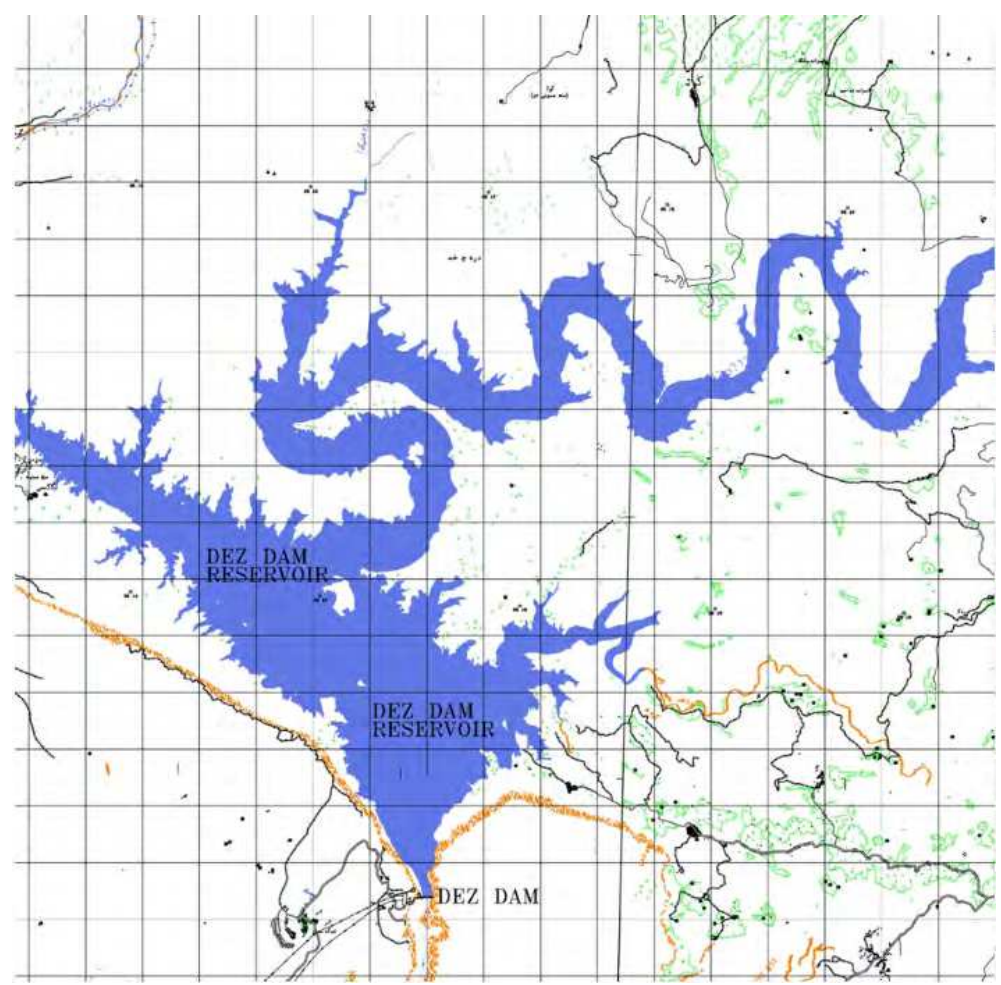

Fig. 2. (a) Photo of Dez Dam Project, (b) A plan view of Dez reservoir 


\subsection{Dez reservoir sedimentation}

Because of importance of sedimentation issues in Dez reservoir, in recent years many field surveys and measurements were conducted by financial supporting of Khuzestan Water and Power Authority (KWPA). These measurements and field investigation is included the following terms:

1. Physical Properties of deposited sediments

2. Mechanical Properties of deposited sediments

3. Volume of deposited sediment

4. Profile and pattern of deposited Sediment in Dez reservoir

\subsection{Physical properties of deposited sediments}

Field measurement was conducted to obtain the undisturbed and disturbed samples from deposited sediment of Dez reservoir close to power intakes (KWPA, 2004). Sediments deposited in Dez reservoir near the dam body have always been as submerged sediments and thickness of water upon the sediments has been more than 50 meters over an operating period of 45 years. In order to survey physical properties of sediment deposited in front of the power intakes, two deep boreholes which they are called boreholes $\mathrm{A}$ and B, were dug near power intakes located at 55 and 100 meter upstream of face of the dam, respectively. Digger was installed on a barge and it was fixed by strong wires which they were anchored to abutments as shown in Fig.3. A piston-type core sampler used to obtain undisturbed samples. The sampler is operated by lowering it until the digger weight touches the sediment surface. With the digger weight resting on the bottom, further lowering of the sampler causes the digger arm to rise and release the coring head. As the cutting sloe is just about to penetrate the sediment, the sampler is penetrated in sediment by hydraulically force so the sampler drives the coring tube into the sediment deposit. The piston remains fixed as the outside tube moves past and serves to fold the undisturbed sample in the tube as it is withdrawn. For boreholes A and B the depth of sampling was 33 and 63 meter respectively in maximum state. During the sampling the height of water above the sediment surface for boreholes A and B was 79 and 76 meter respectively. Height of water for the boreholes was different because time of digging the boreholes was different.

In borehole A, sediment obtained up to depth of 18 meter was very loose so that obtaining undisturbed sample was impossible by piston-type core sampler. From depth of 18 to 33 meter sediments was reported less loss so that obtaining undisturbed sample was possible. In the other hand in borehole A one can see two overall different layers. One layer which it is very loose (soft) sediment is started from sediment surface of reservoir and is continued up to depth of 18 meter. Another layer is more dense sediment and it is which it is started from depth of 18 meter and is continued up to original bed reservoir.

In borehole B, sediment obtained up to depth of 30 meter was very loose so that obtaining undisturbed sample was impossible. From depth of 30 to 63 meter sediments was reported denser so that obtaining undisturbed sample was possible. It should be noted that two overall different layers were found in borehole B as same as for borehole A. 


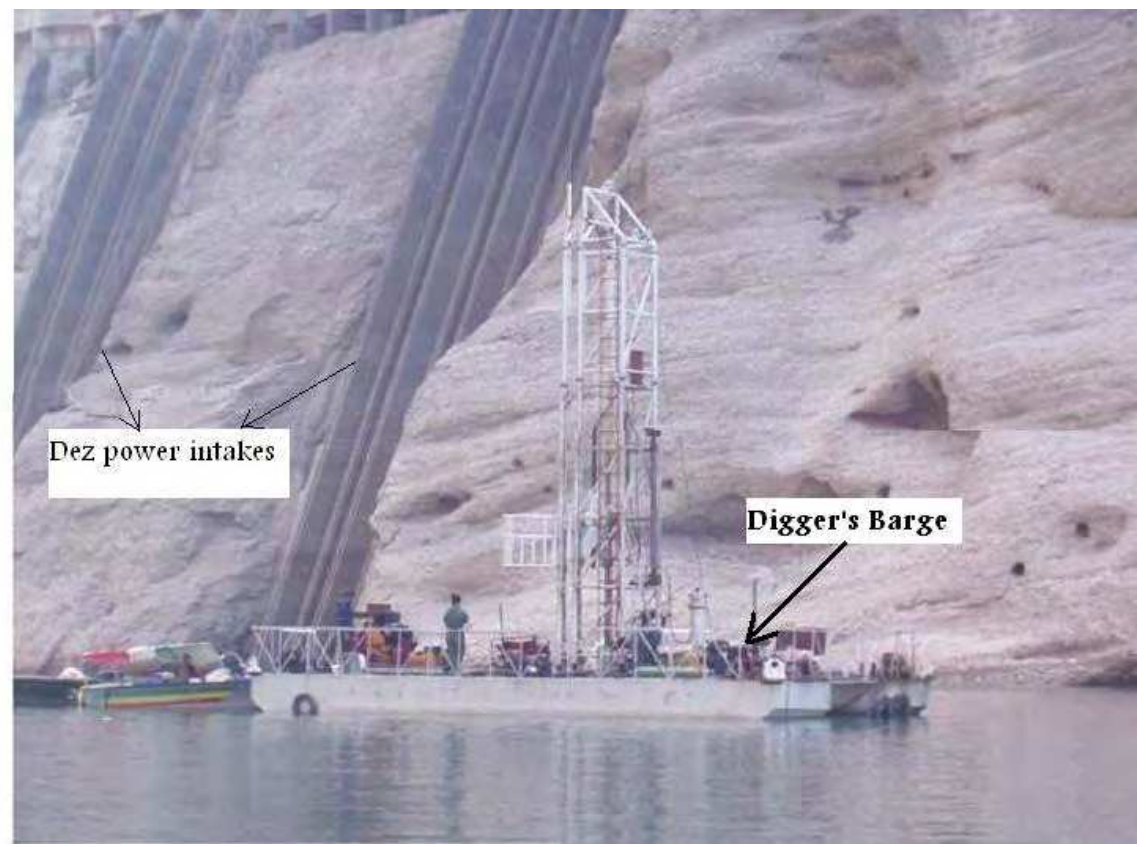

Fig. 3. Photos of barge and digger located near Dez power intakes.

The results of field investigation show that loose sediment region for two boreholes are different. It refers to different location for the boreholes. The borehole $\mathrm{A}$ is located in front of irrigation outlets (in the river thalweg path) but the borehole B is closed to left abutment of reservoir. As it can be seen a part of sediments in boreholes A and B are very loose. This is because during the past years part of the sediment deposited in the reservoir has been flushed via irrigation outlets forming a wedge in the upstream face of the dam. Years after the wedge have been refilled by new sediment. Therefore sediment deposited in the wedge flushing region has not had much time for consolidating and the sediments have remained is loose stages.

The bulk density of sediments was measured using ASTMD854 procedure and percent of saturated water content were also measured by weighting method. The void ratio of the sediments was calculated based on the following relationship:

$$
e=\frac{\rho_{w} G_{s}-\rho_{\text {sat }}}{\rho_{\text {sat }}-\rho_{w}}
$$

Where $\rho_{\text {sat }}$ is saturated density of the sediments, $\rho_{w}$ density of water, Gs specific gravity of sediment solid. Based on the result of the experiments of the samples obtained from boreholes $A$ and $B$, the relative density of the sediments $\left(G_{s}\right)$ was averagely measured at a value of 2.69 .

The results of measured bulk density are presented in Fig.4. The grain size distribution of obtained sediment samples from boreholes $\mathbf{A}$ and $\mathbf{B}$ are shown in Fig.5. 


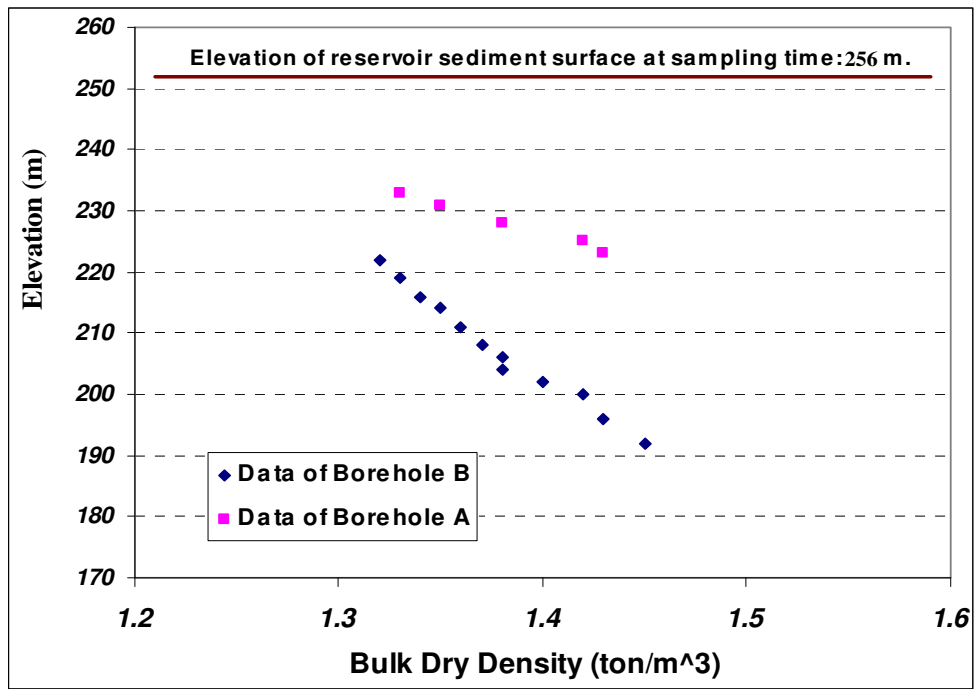

Fig. 4. Measured bulk dry density versus Elevation of sampling for obtained samples from boreholes $\mathbf{A}$ and $\mathbf{B}$.
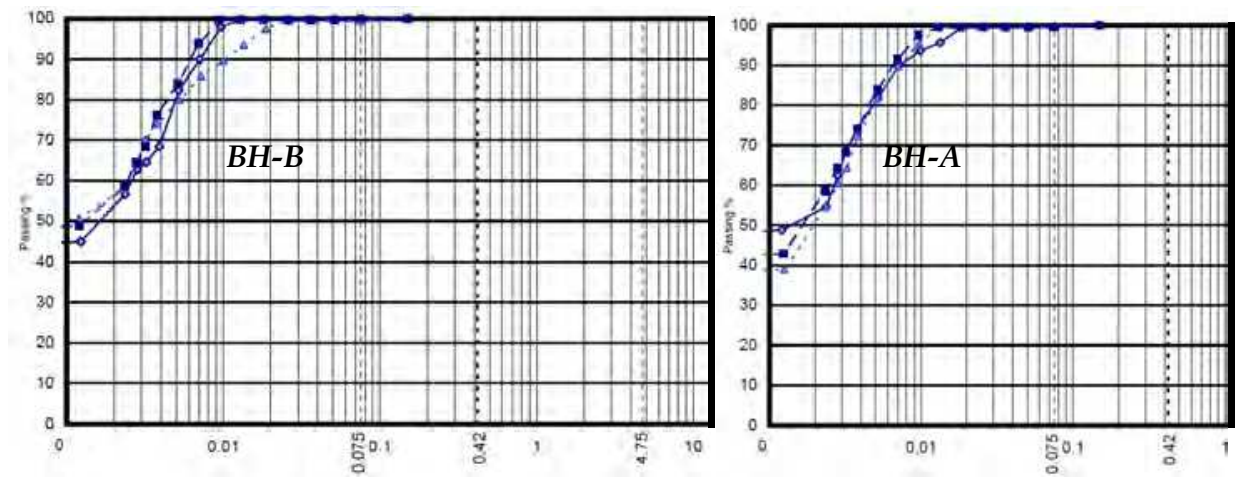

Fig. 5. Grain size distribution curve for obtained samples from boreholes $\mathbf{A}$ and $\mathbf{B}$.

Field measured data obtained from the Dez deep reservoir were applied to evaluate the bulk density of deposited sediment using empirical methods discussed previously. From Fig.5, the percent of clay and silt content in the sediments samples are 55 and 45 percent, respectively. From the Lane's equation, the initial bulk density of the sediments is obtained by $732.8 \mathrm{~kg} / \mathrm{m}^{3}$. This value is an estimated of the initial bulk density for reservoir surface sediment layer which their deposition time is less than 1 year. The measurement conducted of unit weight of sediment at the reservoir bed surface shows a value of $825 \mathrm{~kg} / \mathrm{m}^{3}$ (Samadi Boroujeni, 2005). Comparing of measured and calculated initial bulk density shows that Lara and Pemberton's empirical method predict the initial bulk density $11 \%$ less than that of measured value. This shows that the accuracy of the empirical formula is acceptable. 
Also the Lane's, Miller's and power relationship's methods were applied for various points of A and B boreholes. Obtained results showed that the accuracy of the above empirical methods weren't acceptable, therefor based on the the field data of A and B boreholes, the following relations was developed (Samadi Boroujeni , 2010):

Modified Lane's equation for Dez reservoir:

$$
\rho_{t}=\rho_{1}+1.52 B\left[\frac{t}{t-1}(\ln t)-1\right]
$$

Modified Miller's equation for Dez reservoir:

$$
\rho_{t}=\rho_{1}+2.57 \times B . \log t
$$

Modified Power 's equation for Dez reservoir:

$$
\rho_{t}=1.35 \rho_{1} . t^{0.5 \log \left(1+\frac{2 B}{\rho_{1}}\right)}
$$

\subsection{Progressive deposition in dez reservoir}

The original estimate for sediment accumulation in the Dez reservoir was for a $50 \mathrm{yr}$ volume of 840 million cubic meters (million m3), i.e., equivalent to filling the dead storage within the reservoir to el $290 \mathrm{~m}$. This estimate was made on the basis of there being upstream sediment retention structures and a reforestation program. However, these programs were not carried out. Nevertheless out of an initial reservoir volume of 3,315 $\times$ $10^{6} \mathrm{~m}^{3}$ (at elevation $350 \mathrm{~m}$ ), the available storage in 2002/2003 was found to be $2,698 \times 10^{6}$ $\mathrm{m}^{3}$ (based on the latest bathymetric in 2002/2003) which corresponded to a volume loss of about $615 \times 10^{6} \mathrm{~m}^{3}$ or $19 \%$ of original volume of the reservoir. This result shows that the sediment incoming into the reservoir have been annually $15.7 \times 10^{6} \mathrm{~m}^{3}$. Much of the sediment drops out along the upper reaches to form a delta, which is slowly progressing to the dam, as shown in Fig. 6, while about $11 \%$ reaches the dam in the form of relatively fine sediment transported by turbidity currents. Size distribution analysis of the sediment samples which was taken near the dam showed that the median particle of the sediments was less than $0.01 \mathrm{~mm}$ and it was included $60 \%$ silt and $40 \%$ clay. Although it will take some time for the reservoir to reach its $50 \%$ life, a level normally accepted as the end of effective life, the effect of present sediment inflow on key elements of the project is already of concern. For example the reservoir bed at the face of the power intakes has risen from an original elevation of $180 \mathrm{~m}$ to $256 \mathrm{~m}$ in 2003 at average rate of $2 \mathrm{~m}$ /year over the past operation period, which is only $14 \mathrm{~m}$ below the invert level of the power intake at elevation $270 \mathrm{~m}$ as shown in Fig.7 (Acres and Dezab, 2004). There is now concern that sediment will begin to be drawn into the power tunnels within a decade with potential to damage the turbine runners.

The volume elevation curve for the reservoir when it reaches the end of life condition of $50 \%$ depletion is given in the Fig.8. This figure was obtained by using the empirical area reduction method to derive the volume elevation relationship. The derivation and application of this method is discussed in more detail in the American Society of Civil Engineers Transaction (1960). The methodology was calibrated against the results of the 


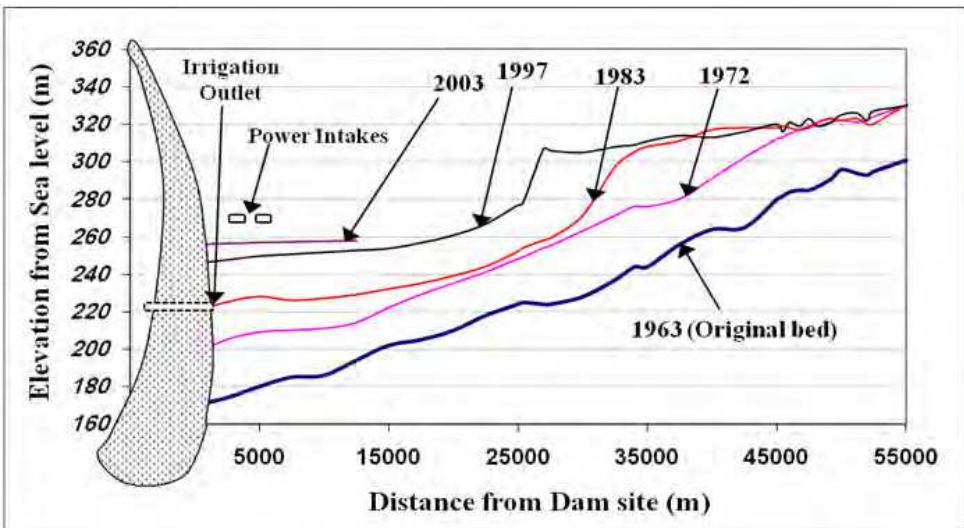

Fig. 6. Sediment longitudinal profile of Dez Reservoir.

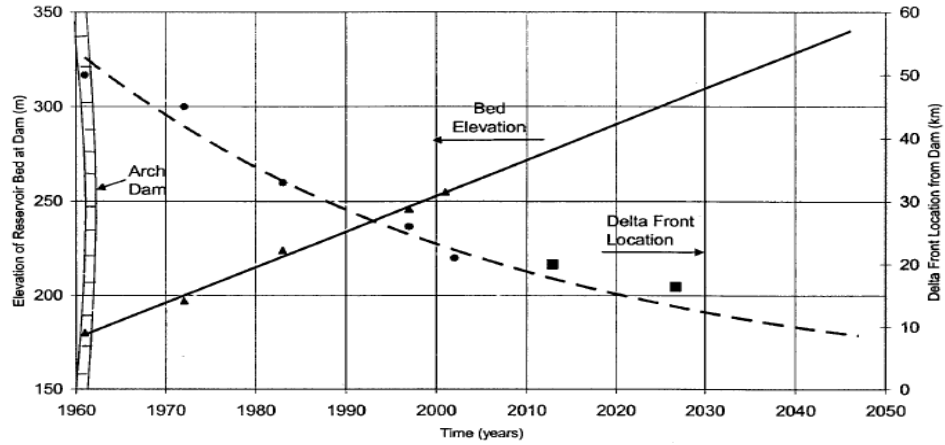

Fig. 7. Progressing Rate of delta front and increasing rate of bed elevation (near Dez dam) versus time based on Longitude profiles of Dez reservoir thalweg in different years.

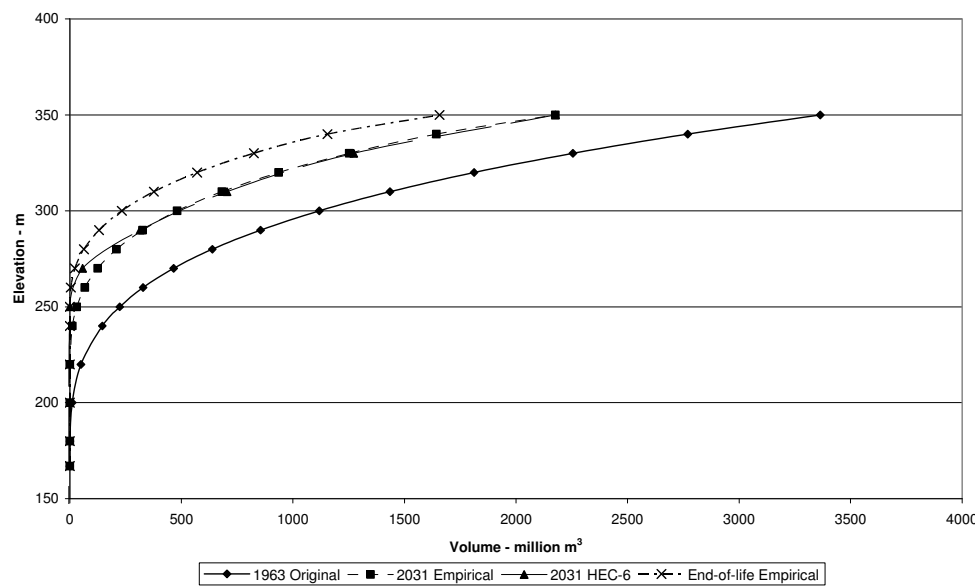

Fig. 8. End of Dez reservoir life volume elevation curve. 
HEC-6 model for the period from 2003 to 20031 (Acres and DezAb, 2004). The Figure shows the comparison of the HEC-6 modeling with the empirical method. The agreement is reasonably good except near the lowest elevations where the configuration of the actual reservoir will differ from the empirical method due to the presence of turbidity current. Also shown is the anticipated volume elevation curve for the reservoir after it is $50 \%$ depleted resulting in a total volume of 1658 million $\mathrm{m}^{3}$.

\subsection{Impacts of dez reservoir sedimentation}

Generally with particular regard to the elements affected by sedimentation these include:

- the reservoir, its remaining live storage and its ability to provide the degree of regulation originally envisaged for the project;

- elements already affected by the passage of water and sediment, including the irrigation outlets, and which may in the future be affected, including turbine equipment, particularly runners and wicket gates.

- Dezful re-regulating dam sedimentation. Since the main function of the re-regulating dam is to make regular the released water from Dez dam hydropower plant in downstream river, the useful volume of storage is, therefore, very important for this dam.

An overview of the reservoir sedimentation situation, its effects on the elements noted above, an indication of the impacts on the project, if remedial work is not implemented, and in this regards, one of the measures proposed to address the sediment management issue is cone flushing of sediment through the dam irrigation outlets. Flushing of sediment has been conducted over the last decade to augment irrigation flows as well as to remove the sediment that has accumulated immediately upstream of the irrigation outlets. This issue has prompted the Khuzestan Water and Power Authority to consider performing the Dez dam flushing operations on the agenda. Predictions indicate that between 1-1.5 million cubic meters of finegrained sediment in the Dez dam Reservoir will be discharged into the downstream river, annually, in the years to come, by performing flushing operations through the Dez dam irrigation outlets (Samadi Boroujeni and Galay, 2004). It should be noted that here are various important constraints during sediment flushing operation via the irrigation outlets such as environmental problems downstream, loss of reservoir water storage, possibility of irrigation outlets clogging by large boulders, the effect of sediment spray around of the power house, and decreasing of power generation, and Dezful re-regulating dam reservoir sedimentation. Since the sedimentation in the re-regulating dam reservoir play an important role in Dez dam flushing downstream effects, it is essential that the sedimentation processes in the reregulating dam reservoir to be simulated for surveying the negative effects of Dez dam flushing operation on downstream. It should be noted that sediment released from Dez irrigation outlets are mostly cohesive sediments therefore this matter should be considered for modeling of sediment transport processes in downstream river.

\subsubsection{Irrigation outlets}

The Dez Dam is provided with three irrigation outlets located at el $222.7 \mathrm{~m}$ within the central blocks of the dam body, some $129 \mathrm{~m}$ below the full supply level of the reservoir. The original function of these outlets was to provide irrigation water to the downstream area, partial flood control and a measure of emergency release. 
Normal operation of the irrigation outlets can be assumed to have occurred for the first 23 years of the project life. However, KWPA operating staff at the dam site advise that flushing of sediment through the irrigation outlets first occurred some 17 years ago and has occurred relatively frequently since then. In early June 2003 sediment had accumulated at the face of the dam to el $256 \mathrm{~m}$, which is over $30 \mathrm{~m}$ above the centerline of the irrigation outlets. Typically flushing of sediment now occurs two to three times each winter.

As a consequence of sediment and trash flushing, the trashracks at the upstream entrance have been damaged to the extent that some of the trashrack bars are missing, the guard valves are leaking at the seats/seals and erosion of the valve stem on all three valves has occurred. Major leakage is evident on the Hollow-cone discharge valves to varying degrees on each outlet. It has also been reported that because of high vibration, the valves are not operated beyond $50 \%$ open (Samadi Boroujeni, 2003).

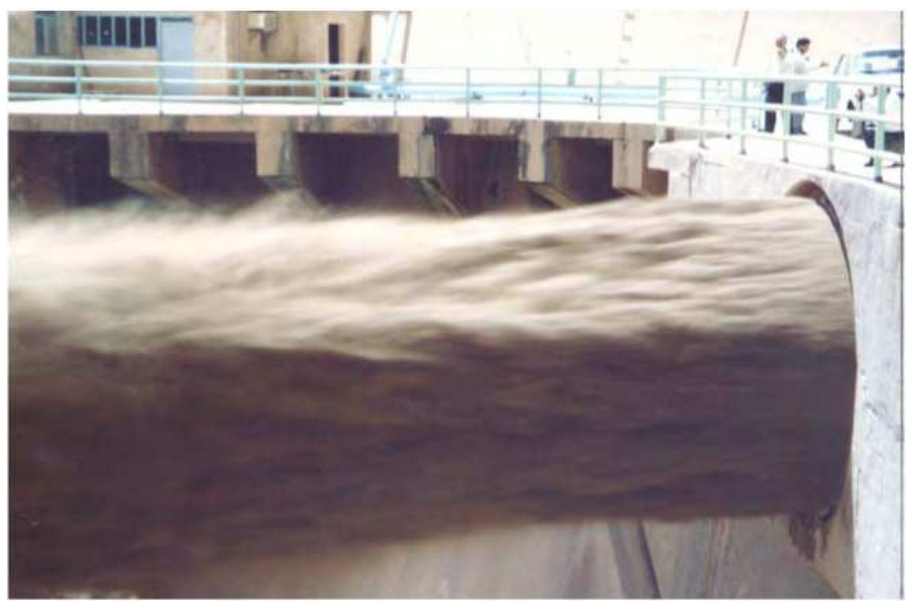

Fig. 9. Photo of Dez Dam Irrigation Outlet, Flushing in June 17, 2003.

\subsubsection{Turbine equipment}

The plant comprises eight 65-MW units with vertical Francis turbines. The maximum operating head for the turbine, given on the nameplate, is $180 \mathrm{~m}$. Each turbine has a butterfly-type turbine inlet valve. Studies are presently underway to upgrade the generating equipment. Given this investment by KWPA it will be important to manage the reservoir sedimentation process with the objective of protecting the units from damaging sedimentladen flows. It will be important to manage the reservoir sedimentation process with the objective of protecting the units from damaging sediment-laden flows.

\subsubsection{The effect of dez reservoir sedimentation on power generation}

Sedimentation in dam reservoir reduces the reservoir storage and it may cause the ability of the reservoir and therefore power generation to be decreased. Samadi-Boroujeni and Kalali (2012), used WEAP model to assess Dez dam reservoir sedimentation effects on hydropower generation. The results, as seen in Fig.10, showed that without Bakhtiari dam (see section 6.6.2), energy production would be decreased by an average rate of $0.08 \%$ per year and in 
scenario of with Bakhtiari dam, the average rate would be $0.06 \%$ per year. In the other hand when the reservoir reach to its half-life, the amount of power generation in comparing with base scenario (by assuming no sedimentation), to be decreased by $9.1 \%$.

a

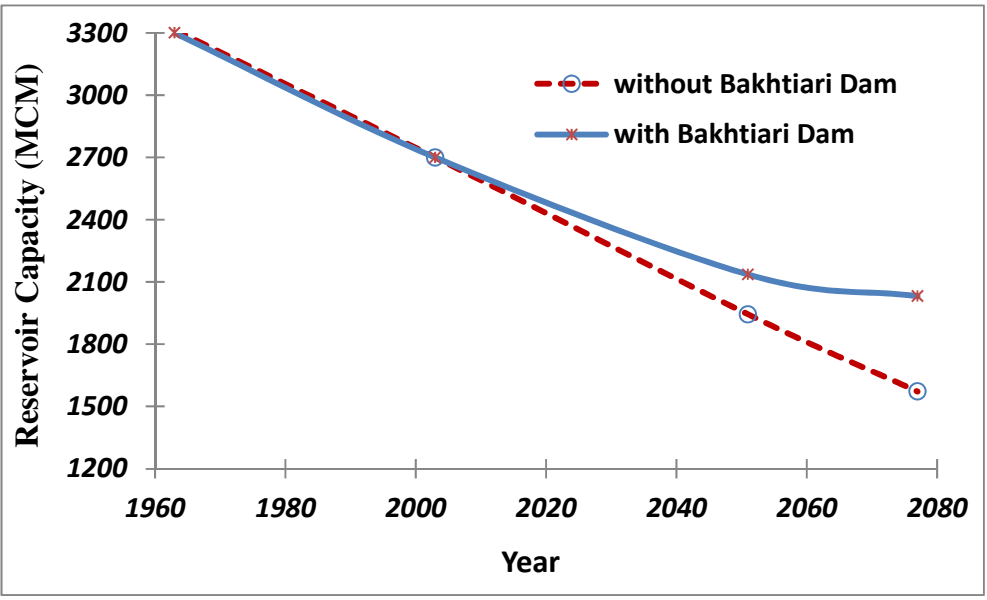

b

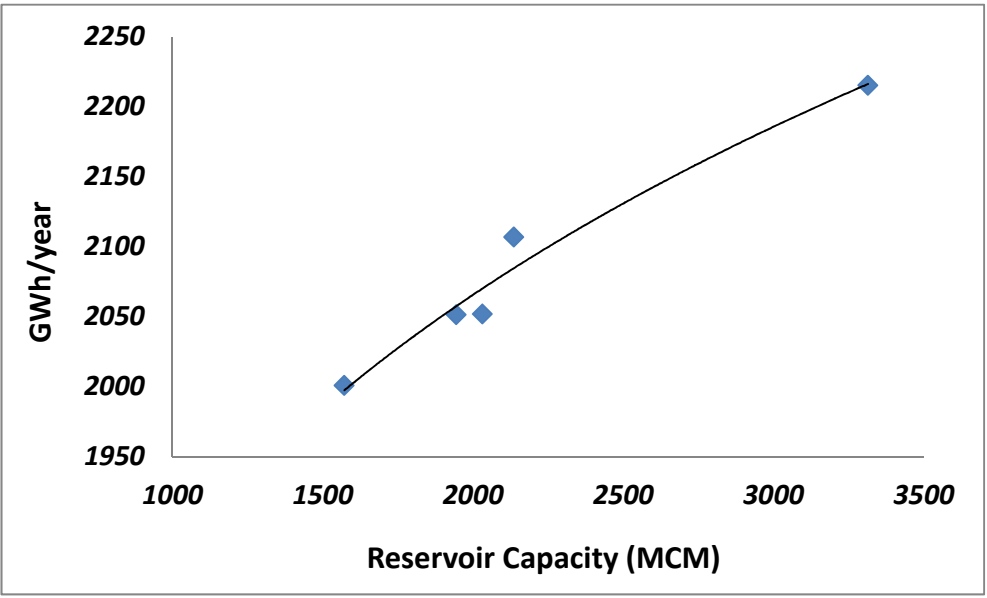

Fig. 10. results from WEAP model: a. reservoir capacity versus time; b. energy production versus reservoir capacity of Dez reservoir.

\subsection{Reservoir sedimentation management alternatives}

Based on literatures and existence experiences, a tentative long-list of alternatives for sediment control of dam reservoirs can be found. The list is sub-divided into four general categories as follows:

i. watershed rehabilitation (Structural and non- Structural Measures)

ii. sediment flushing

iii. sediment routing 
iv. sediment removal and disposal

v. Construction of New power intake

The categories will be described and applicability of each one for Dez reservoir will be discussed. It should be noted that the downstream impacts of Dez dam flushing and proposal of appropriate hydraulic conditions to decrease the negative effects of Dez dam flushing operation on downstream is one of the most important issues.

In anticipation of the need to manage the sedimentation process KWPA has proactively commenced reservoir studies. A tentative long-list of alternatives for sediment control and low-level flushing was initially formulated. The list was sub-divided into the above four general categories. These general concepts were expanded into some 17 alternatives along with several additional sub-alternatives (Acres and Dezab, 2004). A more manageable shortlist of most likely suitable candidate alternatives was then selected including:

- Dam on the Bakhtiari River

- Irrigation outlet rehabilitation and conversion to flushing facility

- Bypass flushing tunnels within the dam abutments

- Excavation in the dry of sediment in the delta

- Dredging near the dam

- Watershed management

- Dam raising.

Acres and Dezab (2004) assessed power system benefits on a system wide basis considering both the effects on the Dez and Karun river systems. Differences in power and energy benefits were determined using Acres Reservoir Simulation program (ARSP model) which has been used extensively in the Khuzestan Province for over more than 20 years. As part of these analyses, irrigation, domestic and industrial water demands on the Dez River were satisfied with varying priorities. The value of irrigation water deficits were calculated for

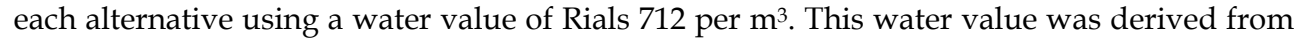
information provided by KWPA regarding the weighted average value of a composite crop and amount of water used to grow this crop. The various sediment management alternatives considered the incremental water, power and energy benefits of each alternative compared to a case of no intervention.

\subsubsection{Watershed management}

The reduction of sediment yield from a watershed is generally accomplished by measures such as erosion check structures, terracing and tree planting. From overflights and inspection of satellite images it appears that measures would be difficult to construct in the Bakhtiari watershed because of steep canyons and no access roads. In addition measures in the upper watershed of the Tireh and Marloreh Rivers would not serve any purpose because sediment yields are very low. Therefore, the study of erosion reduction measures was confined to the Northwest portion of the watershed, namely the Keshvar and Girit Rivers. From brief studies by DRC (1972), by DezAb and Acres (2004 and 2005) and with due regards to the status of the watershed management activities over the past 40 years, approximate estimates show that the reduction in sediment yield would range from 10 to 15 percent of the annual yield for the entire basin. However, this alternative would not result in immediate reduction because implementation of check structures and road construction would take many years. Therefore, this alternative was ranked as having a low status. 


\subsubsection{Dam on the Bakhtiari river}

Several dam sites are being studied on the Bakhtiari River and preliminary plans indicate that the first dam could be completed by 2018. The Bakhtiari reservoir could trap about 55 percent of the annual sediment load of the entire watershed and would double the active life of the Dez Reservoir. Although the power and energy economics of this alternative were not evaluated, it would contribute to significantly reducing the sediment accumulation in the Dez reservoir and is therefore ranked high on the list.

\subsubsection{Flushing sediment through the irrigation outlets}

Flushing of sediment has been conducted over the last decade to augment irrigation flows as well as to remove the sediment that has accumulated immediately upstream of the irrigation outlets. The level of sediment adjacent to the irrigation outlet had reached el. $256 \mathrm{~m}$ in 2003 . At that time a pilot flushing program was conducted from April to June 2003 to assess the headcutting process upstream from the dam and the subsequent concentrations downstream. The findings from the pilot project were as follows:

i. The flushing of the sediment on June 17, 2003 caused a wedge to be headcut upstream from the dam, having a length of $400 \mathrm{~m}$, a width of $90 \mathrm{~m}$ and a maximum depth of $26 \mathrm{~m}$ at the dam face (Fig. 11). This results in approximately $470,000 \mathrm{~m}^{3}$ of fine sediment being flushed in about 4 hours.

ii. The flushing was undertaken during low flow into the reservoir with no turbidity current arriving at the dam.

iii. The suspended sediment concentration downstream from Dez Dam, at the regulatory structure, rose from a low value of about $100 \mathrm{mg} / 1$ to $8,000 \mathrm{mg} / 1$ and this high concentration lasted for about one day (Fig.12).

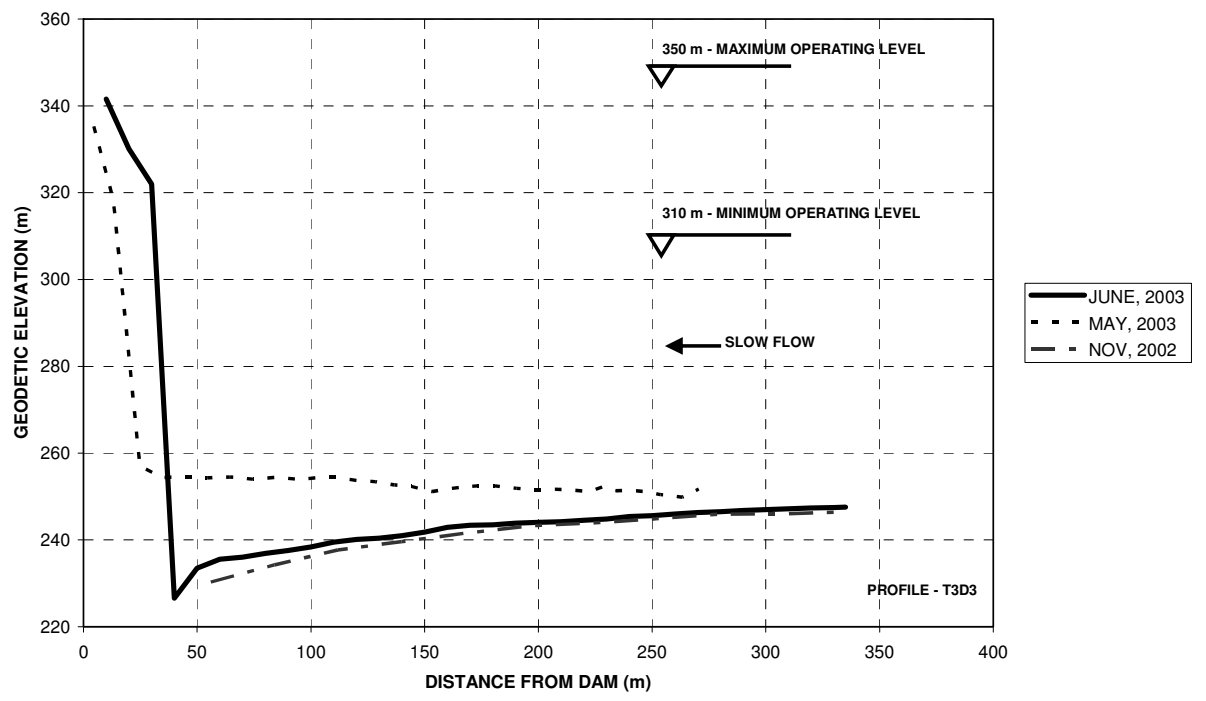

Fig. 11. Filling and flushing of Dez gorge upstream from Dez dam. 


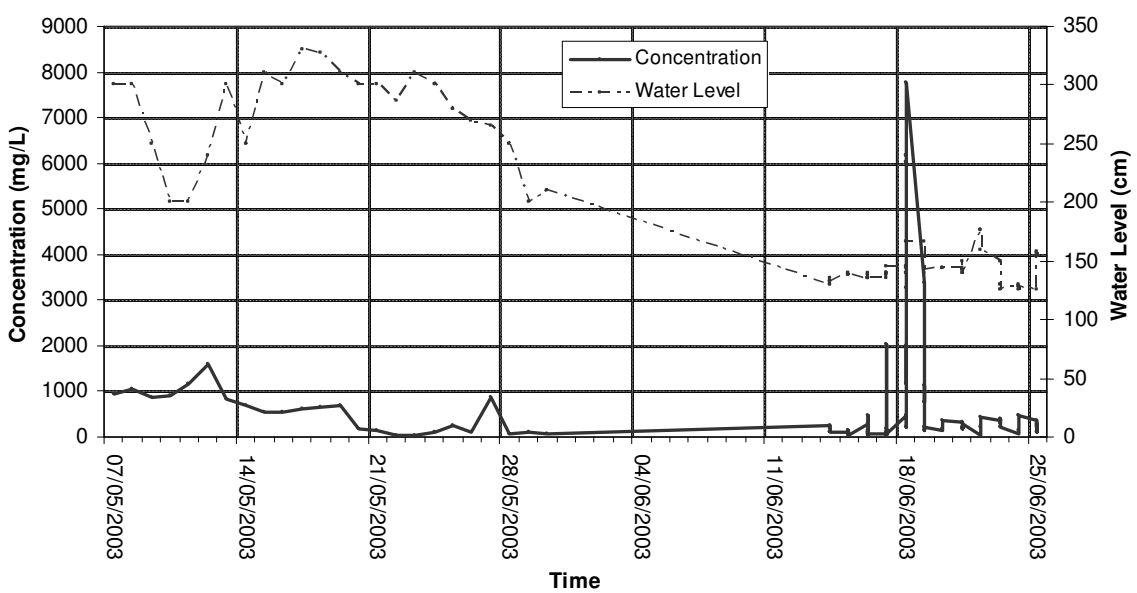

Fig. 12. Sediment concentration and water levels for Dez-Harmaleh.

The pilot project generally indicates that wedges (or slugs) of sediment of about $500,000 \mathrm{~m}^{3}$ can be flushed from the reservoir if a turbidity current has previously filled the narrow wedge to about elevation $250 \mathrm{~m}$. From analysis of historical peak flows entering the reservoir, it was shown that about 2.2 million $\mathrm{m}^{3}$ of sediment could be brought to the dam annually by turbidity currents - the balance of the inflowing sediment, about 14 million $\mathrm{m}^{3}$ would be deposited on the delta and in the lake portion of the reservoir. Therefore, the flushing of sediment should be closely coordinated with the inflow of turbidity currents, but this would remove only about 10 percent of the annual sediment inflow. However, such wedge flushing has the advantage of causing the sediment surface level at the face of the power intakes to be effectively decreased.

Samadi Boroujeni, et al. (2010) modeled the Dez dam flushing through the irrigation outlets by using MIKE11 model. MIKE11 model is able to solve the equation of mass transport and can be used for the simulation of cohesive sediment transport in the reservoir. Results obtained from MIKE11 model showed that manner of carrying out the flushing for the Dez dam sediments influences the trapping efficiency of re-regulating dam reservoir and one can, therefore, reduce the sedimentation in the re-regulating dam reservoir through proper management at the Dez dam flushing. The same results indicate that the less duration of flushing operations at the Dez dam and the more discharge from re-regulating dam will decrease trap efficiency coefficient in the re-regulating dam reservoir. This, however, causes the concentration of outflow from the re-regulating dam to be more than the allowable level of concentration at the downstream river. If all the factors involved in decision-making, such as the loss of Dez reservoir water storage, threat of flooding downstream, sedimentation in the reservoir of re-regulating dam, downstream environment, and risk of opening the Dez dam outlets are considered to have equal degrees of impact, the option that the irrigation outlets (sediment discharge) are opened for two times with a total discharge of $30 \mathrm{~m}^{3} / \mathrm{s}$, the duration of performing the flushing operation being 6 hours each time at a minimum 6-hour interval between the two flushing, will gain the lowest impacts and therefore, it will be the most appropriate option. To decide which option is the best flushing manner, the beneficiary administration needs to pay attention to the relevant conditions and to consider 
the incremental as well as minimal coefficients for each criterion, and to calculate the total scores of each option.

\subsubsection{Bypass flushing tunnels within the dam abutments}

Consideration was given to re-opening the existing diversion tunnel, which had been plugged following the original construction of the project, and adapting it and an access tunnel to a sediment flushing tunnel. The intake to the diversion tunnel is at elevation $184 \mathrm{~m}$ which means that it is under a 50 to $70 \mathrm{~m}$ thickness of sediment which may require dredging prior to re-opening the tunnel. Alternatively, the sediment may be removed during the initial blast, resulting in rapid headcutting and a slug of sediment in the downstream river with concentrations as high as $500,000 \mathrm{mg} / 1$ for possibly 6 hours. This sediment slug would be damaging to downstream fish habitat and recreation and therefore it would be required that the sediment concentration be decreased by spillway and turbine flows.

\subsubsection{Venting of turbidity currents}

Field measurements of turbidity currents in the Dez Dam reservoir in Jan 2002 to July 2003 showed that turbidity currents occur when the river is flooded (Samadi-Boroujeni and Galay, 2004). The preliminary results indicate the following information:

i. at high reservoir levels, the turbidity current is indicated at the upstream end of the reservoir and as it moves over the delta foreset slop fine sediment is entrained into the current.

ii. tow current were tracked with suspended sediment concentration up to $7000 \mathrm{mg} / \mathrm{l}$ and the volume of sediment moving within the current in January 28, 29, 2003 was 44,000 $\mathrm{m}^{3}$ while larger event of Aprial 23, 24, 2003 was 1,188,500 m³/year;

iii. after analysis of 26 years of high flow events and using a relationship between peak flow events and turbidity loads determined in 2003, one obtains an annual turbidity current of about 2,243,200 $\mathrm{m}^{3} /$ year;

iv. the estimate of annual turbidity load amounts to approximately 13 percent of the annual sediment inflow to the reservoir.

From this information it appears that the extension of reservoir life by flushing of turbidity currents would not be large, but could be economically viable provide that downstream environment guidelines could be adhered to. This event occurs two to four times per year and if the rehabilitation of the irrigation outlets or the bypass flushing tunnels within Dez dam abutments to be performed, the turbidity current can be vented from the reservoir by opening the outlets or the tunnels.

\subsubsection{Excavation in the dry of sediment in the delta}

A brief study indicates that this alternative would be rather expensive, with high costs for road construction necessary to truck the excavated sediment to disposal sites and possibly to improve cropland. The excavation site would be somewhere between $\mathrm{km} 35$ and 45 , upstream of the dam, and would require a bridge so that excavation could occur on both sides of the active channel. This alternative is, however, difficult to implement as hundreds of trucks would have to be loaded every day to excavate about 10 percent of the annual 
sediment load which is about 16 million $\mathrm{m}^{3} /$ year. The annual operating cost could be as high as $\$ 5$ million which with a high initial capital cost makes this alternative unattractive.

\subsubsection{Dredging near the dam}

Dredging near the dam would require a special dredge capable of operating in water depths of 100 to $120 \mathrm{~m}$ which would be expensive. The dredge spoil could be pumped to the spillway tunnels. This alternative was ranked low.

\subsubsection{Dam raising}

Dam raising would considerably increase the effective volume of the reservoir. Structural analysis of the raised dam shows potential limitations with any large height increase due to the high seismic loads in the region. Raising the dam $10 \mathrm{~m}$ shows large increases in joint opening during extreme earthquake (Acres and Dezab, 2004). From preliminary results, it is recommended that the maximum extent of dam height increase be limited to not more than $10 \mathrm{~m}$. In this case the added effective volume after $10 \mathrm{~m}$ of dam raising, would amount to about 700 million $\mathrm{m}^{3}$, which is approximately equal to the sedimentation volume from the start of operation to date. Economic analysis shows that, the present value of costs and benefits, for a $10 \mathrm{~m}$ dam raising, will result in a positive net benefit to the project, anticipated to be in the order of 900,000 Million Rials.

Other impacts of the dam rising can be summarized as follows:

- Spillway

For a 10-m raised dam, the maximum spillway discharge capacity would increase from the present capacity of $3000 \mathrm{~m}^{3} / \mathrm{s}$ to $4300 \mathrm{~m}^{3} / \mathrm{s}$. This rate of discharge could have serious consequences including potential erosion damage of the gorge wall, cavitation damage potential at inlet and outlet of the spillway tunnels.. Thus it has been recommended to maintain the present discharge rate of the spillway. In a raised reservoir condition, some modifications will be required at the inlet structure. For example the radial gates should be replaced and a lintel beam provided.

\section{- $\quad$ Power Generation}

For a $10-\mathrm{m}$ dam raising, the water passages are generally capable of handling the extra loads. Some existing leakage might increase or new leakage may occur, but is expected to be controllable. The provision of more efficient generating equipment would be the major change. Average energy production of Dez hydropower with a $10 \mathrm{~m}$ dam raising would be up to $2600 \mathrm{GWh} / \mathrm{yr}$ which is about $8 \%$ more than that of without dam raising option.

- Access Tunnels

To provide access to the raised dam crest elevation, new access tunnels have to be excavated. These tunnels branch from the existing main access tunnel and are of rather short length. Construction of this part is simultaneous with construction activities on the spillways.

- $\quad$ Reservoir Rim and Environmental Issues

For a $10 \mathrm{~m}$ dam raising, three small villages would be flooded and their habitants should be resettled. There is no interference between the raised reservoir and the adjacent railroad. 
Inundation of reservoir rim does not cause major change in environmental condition of the reservoir.

\subsubsection{Flushing of sediment from upstream}

Diversion of sediment from upstream is an approach to mange of Dez reservoir sedimentation. For this purpose many alternatives for a tunnel path were surveyed and ultimately with considering geological conditions, the best path was selected by Emamgholizadeh et al (2005), as seen from the topographic map in Fig.13. This path is shorter than all other options which is approximately $15 \mathrm{~km}$ in length, and its outlet is out of the river system, thus negating any environmental impacts downstream. In addition, we can reclaim the gravel land of the Andimeshk region (Outlet in Fig.13) by means of disposed flushed sediment. The proposed method for flushing of the delta sediments of Dez reservoir include erecting a submerged dam at location A-A and a diversion tunnel, as shown in Fig.13. In this method, the flushing is started when the water surface of reservoir is drawn down to the crest of the submerged dam. During the flushing, the water requirement for power generation would be supplied by water storage existing between Dez dam and submerged dam which in this paper will be termed named the main reservoir (M-R), (Fig $13,14)$ after flushing operations, the gate of the diversion tunnel will be closed and the area upstream of the submerged dam, which in this paper is termed the upstream reservoir (U.R), (Fig 13,14) will be refilled and the water surface will rise again up to the crest of the submerged dam.

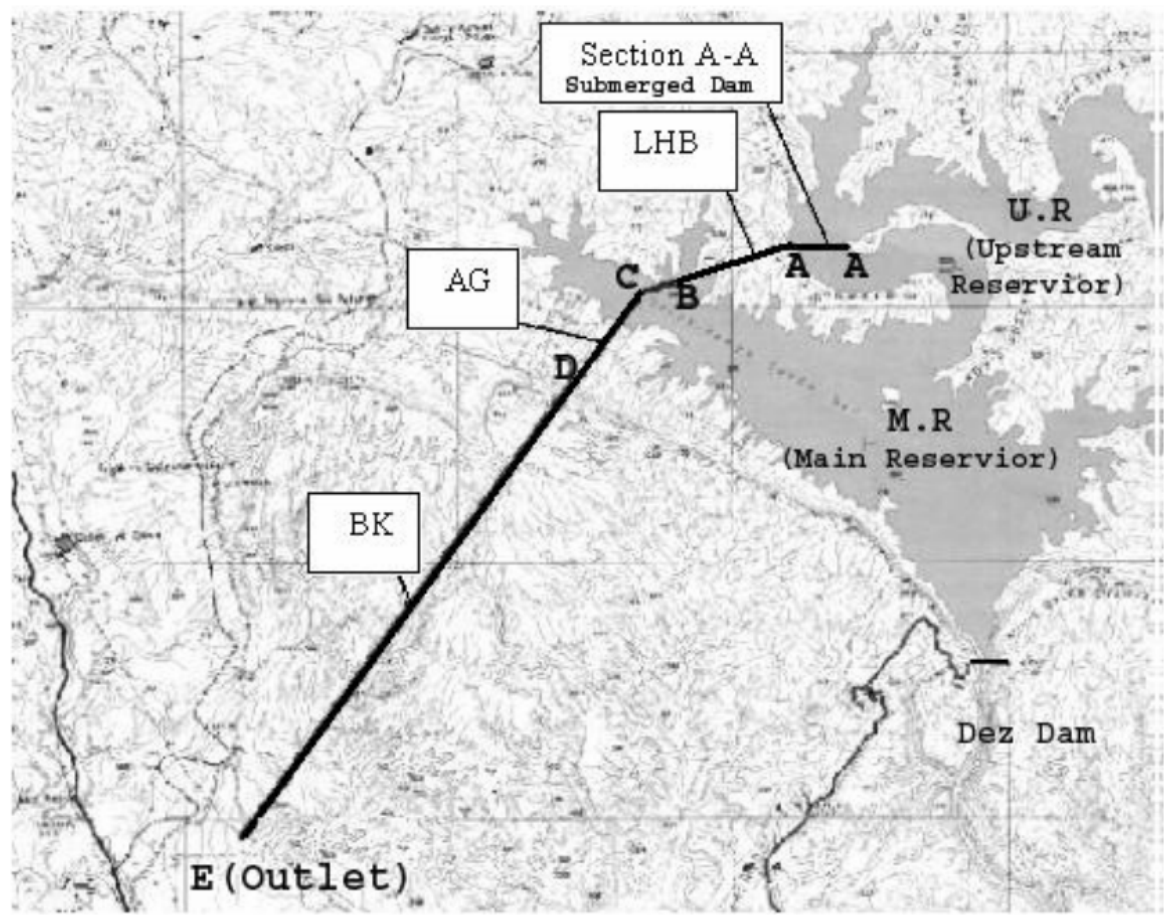

Fig. 13. Layout of diversion tunnel (path ABCDE). 


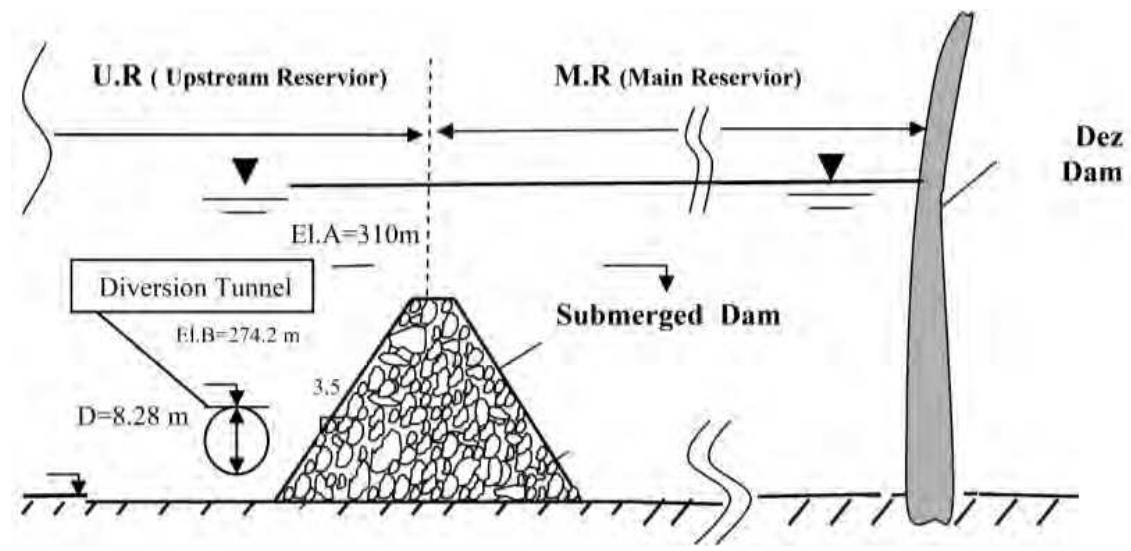

Fig. 14. location of submerged dam (Section A-A from Fig. 13) and outlet of diversion tunnel.

The dimensions of the diversion tunnel and the submerged dam will depend on the hydraulic and hydrological aspects of flushing and economic considerations.

- $\quad$ The most suitable period for flushing operations

Since in normal conditions, flushing operations are used to dispose the deposited sediments from the upstream submerged dam (U.R), the best time to carry out flushing operations is when the reservoir elevation is at minimum operating level. Based on the Dez Dam Rule Curve, this period is during the months of Dec, Jan, and Feb.

- The transporting capacity of flushing flows

The transporting capacity of flushing flows can be estimated by using an empirical equation that is reported in IRTCES (1985). This equation is:

$$
Q_{S}=\psi \frac{Q_{f}^{1.6} \cdot S^{1.2}}{W^{0.6}}
$$

Where $\mathrm{Q}_{\mathrm{S}}=$ the sediment transporting capacity (ton/sec); $\mathrm{Q}_{\mathrm{f}}=$ the flushing discharge $\left(\mathrm{m}^{3} / \mathrm{sec}\right) ; \mathrm{S}=$ the bed slope; $\mathrm{W}=$ the channel width $(\mathrm{m})$; and $\Psi=$ constant parameter that is dependent on the size of the sediment. With respect to the type of sediments in the Dez Dam (D50>0.1mm), this parameter is selected to be 300 . Based on the regime theory, the bed slope should be about $0.0010 \mathrm{~m} / \mathrm{m}$.

After flushing begins, the flushing channel created in the sediment deposits will be selfformed, and its width can be controlled principally by the discharge flow, slope and sediment properties. However, the channel formed during flushing has been found to correlate well with sediments derived from flushing discharge $\left(\mathrm{Q}_{\mathrm{f}}\right)$ alone. The flushing equation which was derived from the data presented by IRTCES (1985) can be applied for the calculating of the channel width $(\mathrm{W})$ :

$$
W=12.8 Q_{f}^{0.5}
$$


Thus, with $Q_{f}=200$ the channel width $(W)$ is calculated $181 \mathrm{~m}$. Based on this equation, the transporting capacity of flushing flows is calculated as 16 ton/sec.

To estimate the volume of sediments that can be eroded by flushing, it is necessary to determine the geometry of the flushing channels. The channel bed width is calculated as 78 $\mathrm{m}$ and the side slope of flushing channel can be determined by the following equation [Teissin, 1991]:

$$
\tan \alpha=\frac{36}{5} \rho_{d}^{4.7}
$$

Thus, $\rho_{d}=0.8$ ton $/ \mathrm{m}^{3}$, the side slope of the flushing channel $(\alpha)$ is calculated $65.6^{\circ}$.Before sediment flushing, the delta sediments bed slope is 0.0005 and after that, it would be 0.0015.With due regards to the information provided, the volume of the flushing channel can be calculated as $9.3 \times 10^{6} \mathrm{~m}^{3}$. It is assumed that flushing operation would be carried out once per year.

Criteria for determining whether flushing in a particular reservoir has been successful are required. One of the methods to designate the criteria for successful flushing is the Sediment Balance Ratio (SBR), which is defined as sediment mass flushed annually divided by sediment mass depositing annually [Atkinson, 1996]. If $S B R>1$ then sediment balances can be obtained. For the proposed flushing method, since the sediment flushed and the sediment deposited have been calculated as 9.3 and $17 \times 10^{6} \mathrm{~m}^{3}$ respectively, the SBR ratio will be 0.55 . Another term for the evaluation of flushing is Flushing Efficiency (Fe), which is defined as the ratio of deposited volume eroded to the water volume used during flushing over any time interval [Atkinson, 1996]. An alternative expression for flushing efficiency is the Water Sediment Ratio (WSR) which is the inverse of the Fe. Since the transporting capacity flows and the total of the flushed sediments volume have been calculated as 16 ton/s and $9.3 \times 10^{6} \mathrm{~m}^{3}$ respectively, therefore duration of flushing operation is calculated 8.1 day and waste water will be $140 \times 10^{6} \mathrm{~m}^{3}$. In this calculation it is assumed that bulk density of the sediment to be 1.2 tons $/ \mathrm{m}^{3}$.According to the aforementioned information, the WSR ratio for Dez Reservoir will be 15.05 .

\section{Conclusion}

In this chpter reservoir sedimentation and sediment management measures were presented and the sediment problems in Dez dam reservoir, as a case study, was disscused. Also a comprehensive introducing and evaluation of the various alternatives was briefly undertaken by considering the technical and environmental issues of each alternative.

In addition to the technical details of each alternative the effects of various sediment management alternatives on the life of the reservoir were considered. For this purpose a "useful reservoir life" corresponding to $50 \%$ of the initial reservoir volume, which it also call resrvoir half-life, was assumed. The initial volume of the Dez reservoir was estimated to be 3316 million $\mathrm{m}^{3}$, thus the $50 \%$ storage depletion volume is approximately 1658 million $\mathrm{m}^{3}$. Understandably the major effect on the "useful reservoir life" comes from those alternatives which directly increase the reservoir volume or intercept the sediment entering the Dez reservoir, namely Dez dam raising or construction of the Bakhtiari dam. 
Surveys undertaken in the Iranian years 1381 and 1382 (2002 and 2003) show that, after 40 years of operation, some $81 \%$ of the original Dez reservoir volume remains. Sediment is entering the reservoir at an average rate of about 15.8 million $\mathrm{m}^{3} / \mathrm{yr}$. Coarse sediment deposition is occurring in a delta area, which is presently about $27 \mathrm{~km}$ from the dam, while the finer silt and clay fractions are transported beyond the delta. The delta is progressing downstream at a rate of about 0.5 to $1.0 \mathrm{~km} /$ year.

The fine sediments carry about 2.2 million cubic meters which settle out in the main body of the reservoir or are transported to the dam area. These suspended sediments travel in density currents and are reflected by, and deposited near, the dam, increasing the depth of sediment at this location by about $2.0 \mathrm{~m} /$ year. Accordingly the hydro-mechanical equipment within the dam body is being affected by the sediment laden flows and without interventions the powerhouse turbine equipment will be similarly affected in the near term. To assess Dez dam reservoir sedimentation effects on hydropower generation WEAP model was used (Samadi-Boroujeni and Kalali, 2012). The results showed that when the reservoir reach to its half-life, the amount of power generation in comparing with base scenario (by assuming no sedimentation), to be decreased by $9.1 \%$.

It was important to distinguish between sediment management alternatives which consider different issues. Two key categories of alternatives were identified, those that directly address the power intake sediment issue and those that address the wider issue of reservoir sedimentation and storage.

Power intake sedimentation was found to be best addressed by flushing the sediment through rehabilitated irrigation outlets. However, flushing is only effective in transporting sediment from the wedge area in close proximity to the dam, essentially to clear the passage to the irrigation outlets and to protect the power intakes. Subsequently, flushing will remove some or all of the turbidity current as it arrives at the dam and before it deposits. For this purpose an operational procedure is required that involves the passage of flows at various intervals, coordinated with power and spillway flows, to control downstream sediment concentrations and to allow water clearance time, both of which are required to address the present downstream fisheries operations. Initial planning of such an operation has been based on environmental criteria which have yet to be made specific to Iran and the Dez River. Thus operational experience is required to be gained over time as the flushing operations are implemented. Although the rehabilitated irrigation outlet alternative had a limited net present value of benefits it had the added benefit of maintaining reservoir drawdown capabilities and of being implemented in a relatively short period of time.

Sediment removal of the delta material by dredging is not considered to be a viable alternative due to the expected high cost of operation and maintenance. The alternative of machine excavation at times of low reservoir has been evaluated as part of this study, although only about $7 \%$ to $10 \%$ of the annual sediment inflow could be excavated by this method. Also diversion of sediment from upstream was an approach to mange of Dez reservoir sedimentation that surveys showed that this option is possible by constructing a submerge dam with a height of approximately 80 meters and a tunnel approximately $15 \mathrm{~km}$ in length at midrate location of Dez reservoir. By this measure a total sediment volume of 9.3 MCM per year can be discharged from the reservoir. The Sediment Balance Ratio (SBR) for this option was obtained 0.55 and total cost for that was estimated 176 million US\$. It is so extensive comparison with irrigation outlet rehabilitation option. 
Dam raising would considerably increase the effective volume of the reservoir (approximately 70 million $\mathrm{m}^{3}$ for each meter of dam raising). In general it is considered that the various technical issues involved in dam heightening can be addressed. However, further refined study is required of the dam body which was found to have significant stress and deformation conditions both under static and dynamic load conditions to the extent that the maximum height increase may be limited to about $10 \mathrm{~m}$.

Construction of the Bakhtiari dam in upstream basin of Dez Dam, perhaps in the period 2014 to 2018 would further reduce the sediment entering the Dez reservoir, but at great cost. It will trap about $50 \%$ of total sediment inflow to Dez reservoir so it can be addressed as an efficient measure.

Results obtained from the use of MIKE11 model for flushing option through irrigation outlets showed that if the irrigation outlets (sediment discharge) to be opened for two times with a total discharge of $30 \mathrm{~m}^{3} / \mathrm{s}$, the duration of performing the flushing operation being 6 hours each time at a minimum 6-hour interval between the two flushing, it will gain the lowest impacts and therefore, it will be the most appropriate option.

\section{Acknowledgements}

I wish to acknowledge the Khuzestan Water and Power Authority and Shahrekord University, Iran for their assistance and guidance provided in the preparation of this chapter.

\section{References}

[1] Acres and Dezab, (2004), “Dez Dam Rehabilitation Project- Stage1: Sedimentation Study", Report to KWPA, Ahwaz, Iran.

[2] Acres and Dezab, (2004), "Dez Dam Rehabilitation Project- Stage2: Irrigation Outlet Study", Report to Khuzestan Water and Power Authority, Ahwaz, Iran.

[3] Atkinson, E., (1996) "The feasibility of flushing sediments from reservoirs", Report OD 137, HR Wallingford, UK.

[4] Brandt, A., (2002)“A review on reservoir desiltation”, International journal of sediment research. 307-320.

[5] Batuca, D, G \& Jordan, J. (2000) "Silting and Desilting of Reservoirs". USA: Balkema.

[6] Basson, G. (2002). "Mathematical Modelling of Sediment Transport and Deposition in Reservoirs-Guidelines and Case Studies, " Inter zational Commission on Large Dams Sedimentation Committee Report.

[7] Chao, P.C. and S. Ahmed. (1985) A mathematical model for reservoir sedimentation planning. Water Power \& Dam Construction, Vol. 37, No. 1, Jan. p.45-52.

[8] Chikita, K., N. Yonemitsu and M. Yoshida (1991) Dynamic sedimentation processes in a glacier-fed lake, Peyto Lake, Alberta, Canada. Japanese. J. of Limnology, Vol.52, No.1, p.27-43.

[9] DHI, (2000), Reference Manual MIKE11 Model.

[10] Emamgholizadeh, S., H.Samadi-Boroujeni, and M.Bina, 2005, "The Flushing of the Sediments Near the Power Intakes in the Dez Reservoir", Proceeding, The Third International Conference on River Basin Management, Italy.

[11] Fan, J. and G.L. Morris (1992) Reservoir Sedimentation II: Reservoir desiltation and long-term storage capacity, J. Hydr. Engrg., Vol. 118, No.3, p.370-384. 
[12] Garcia, M.H. (1993) Hydraulic jumps in sediment-driven bottom currents. J. Hydr. Engrg., ASCE, Vol.119, No.10, p.1094-1117.

[13] Gebrehawariat, G., and Haile. H. (1999). Reservoir Sedimentation Survey Conducted on Four micro dams in Tigray. Commission for Sustainable Agriculture and Environmental Rehabilitation in Tigray, Ethiopia.

[14] Khusestan water and power Authority. (2003). "Field measurement of turbidity current in Dez Dam reservoir".

[15] Lara, J.M., and Pemberton, E.L. (1963). Initial Unit Weight of deposit sediments. Proceedings of the Federal Inter-Agency Sedimentation Conference, Paper No. 82., USDA.

[16] Lane, E.W., and Koelzer, V.A., (1943), "Density of Sediments Deposited in Reservoirs," Report No.9. In A Study of Methods Used in Measurement and Analysis of Sediment Loads in Streams. Hydraulic Lab, Iowa University.

[17] Mahmood, K. (1987) Reservoir sedimentation: Impact, extent, and mitigation. Techn. Paper No.71, The World Bank, Washington D.C., USA.

[18] Morris,G.L. and J.Fan, (1998),"Reservoir Sedimentation Handbook", McGraw-Hill, New York, USA,

[19] Molanezhad, M., (2008), Development of Eco-Efficient Water Infrastructure In Iran, UNESCAP Workshop10-12 November 2008 , Republic of Korea.

[20] Miller, C.R., (1953), "Determination of the Unit Weight of Sediment for Use in Sediment Volume Compaction", USBR, Denver.

[21] Pazwash, H. (1982) Sedimentation in reservoirs case of Sefidrud dam. Proc. 3rd Congress of the ADP, IAHR, Bandung, Indonesia, Vol. C, Paper Cc7, p.215-223.

[22] Sadeghi, M. A. (2002) "Surveying the Trend of Sedimentation in the Dez Re-regulating Dam Reservoir Using the BRI-STARS Mathematical Model, Faculty of Agriculture, University of Shahid-Chamran, Ahwaz, Iran, Dissertation (M.S. Thesis).

[23] Samadi-Boroujeni, H. (2004), "Prediction of Sediment Concentration Resulting from the Dez Dam Hydraulic Flushing Operations at the Downstream River Along with a Survey of its Environmental Impacts", Report of Research project, Khuzestan Water and Power Authority, Iran.

[24] Samadi-Boroujeni, H. (2005), "Modeling of Sedimentation and Consolidation of Cohesive Sediments", Faculty of Water Engineering, University of ShahidChamran, Ahwaz, Iran, Dissertation (Ph.D. Thesis).

[25] Samadi-Boroujeni, H. and V.J. Galay,( 2005), “Turbidity Current Measurments Within the Dez Reservoir,Iran", Proceeding, 17th Canadian Hydrotechnical Conference,.

[26] Samadi-Boroujeni, H., M.Fathi-oghaddam, M.Shafaie-Bajestan and H.M.V., Samani. (2005). Modelling of Sedimentation and Self-Weight Consolidation of Cohesive Sediments. Sediment and Ecohydraulics Intercoh2005.1stEdn,Elsevier B.V.Oxford,UK, ISBN: 978-444-53184-1:165-191.

[27] Samadi-Boroujeni, H., A.H. Haghiabi, and E. Ardalan, (2010), Determination of appropriate hydraulic conditions to decrease the negative impacts of Dez dam flushing operation on the downstream, International Journal of Water Resources and Environmental Engineering, Vol.2 (1), pp. 001-008.

[28] Samadi-Boroujeni,H. and Kalali, M. (2012), Dez dam reservoir sedimentation effects on hydropower generation. Report of Research project, Water Resources Research Center, Shahrekord University, Iran. 
[29] Scarlatos, P D., Lin Li, (1997), "Analysis of Fine-grained Sediment Movement in Small Canals", Journal of hydraulic engineering, Vol.123, No.3:200-207.

[30] Shafai Bejestan, M., (2008). Hydraulics of Sediment Transport. Shahid Chamran university press, Ahwaz, Iran, 549p.

[31] Sloff, C.J. (1991) Reservoir Sedimentation: a literature survey. Comm. on hydr. and geotechn. engrg., Report No. 91-2, Delft Univ. of Technology, The Netherlands, 126 pp.

[32] Sloff, C.J. (1994) Modelling turbidity currents in reservoirs. Comm. on hydr. and geotechn. engrg., Report No. 94-5, Delft Univ. of Technology, The Netherlands, 142 pp.

[33] Sloff, C.J. (1997) Sedimentation in Reservoirs, Doctoral Thesis, Delft University of Technology, 270 pp.

[34] Tamene, L., Park, S. J., Dikau, R., and Vlek, P. L. G. (2006), Reservoir siltation in the semi-arid highlands of northern Ethiopia: sediment yield-catchment area relationship and a semi quantitative approach for predicting sediment yield, Earth Surf. Process. Landforms, 31, 1364-1383.

[35] Thapa, B., Dahlhaug, O.G, (2003). Sand erosion in hydraulic turbines and wear rate measurement of turbine materials, Int. Conf. on Hydropower, Hydro Africa -2003, $\mathrm{ICH}$, Arusha.

[36] Tolouie, E., J.R. West, and J. Billam (1993) Sedimentation and desiltation in the SefidRud Reservoir, Iran. 


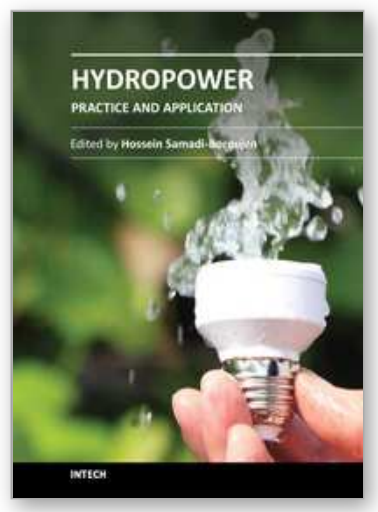

\author{
Hydropower - Practice and Application \\ Edited by Dr. Hossein Samadi-Boroujeni
}

ISBN 978-953-51-0164-2

Hard cover, 320 pages

Publisher InTech

Published online 09, March, 2012

Published in print edition March, 2012

Hydroelectric energy is the most widely used form of renewable energy, accounting for 16 percent of global electricity consumption. This book is primarily based on theoretical and applied results obtained by the authors during a long time of practice devoted to problems in the design and operation of a significant number of hydroelectric power plants in different countries. It was preferred to edit this book with the intention that it may partly serve as a supplementary textbook for students on hydropower plants. The subjects being mentioned comprise all the main components of a hydro power plant, from the upstream end, with the basin for water intake, to the downstream end of the water flow outlet.

\title{
How to reference
}

In order to correctly reference this scholarly work, feel free to copy and paste the following:

H. Samadi Boroujeni (2012). Sediment Management in Hydropower Dam (Case Study - Dez Dam Project), Hydropower - Practice and Application, Dr. Hossein Samadi-Boroujeni (Ed.), ISBN: 978-953-51-0164-2, InTech, Available from: http://www.intechopen.com/books/hydropower-practice-and-application/sedimentmanagement-in-hydropower-dam-case-study-dez-dam-project-

\section{INTECH}

open science | open minds

\section{InTech Europe}

University Campus STeP Ri

Slavka Krautzeka 83/A

51000 Rijeka, Croatia

Phone: +385 (51) 770447

Fax: +385 (51) 686166

www.intechopen.com

\section{InTech China}

Unit 405, Office Block, Hotel Equatorial Shanghai

No.65, Yan An Road (West), Shanghai, 200040, China

中国上海市延安西路65号上海国际贵都大饭店办公楼405单元

Phone: +86-21-62489820

Fax: +86-21-62489821 
(C) 2012 The Author(s). Licensee IntechOpen. This is an open access article distributed under the terms of the Creative Commons Attribution 3.0 License, which permits unrestricted use, distribution, and reproduction in any medium, provided the original work is properly cited. 